\title{
TOURISM-FIRM DIFFERENTIATION AND PLACE DIFFERENTIATION IN THE SUN-SEA-SAND TOURISM CITY OF ANTALYA (1)
} Hilal ERKUŞ-ÖZTÜRK*, Pieter TERHORST**

Received: 31.05.2016; Final Text: 01.02.2017

Keywords: Firm differentiation; place differentiation; innovation; renovation; tourism city; Antalya.

1. This research paper was funded and supported by TUBITAK 1001 Project, named as; "Turizm Kentlerinde Ekonomik Aynılaşma-Farklılaşma: Antalya Öneği" "Economic Diversification and Homogenization In Tourism Cities: The Case of Antalya", Project No:112K443.

2. Earlier versions of this paper, titled as "Homogenization and Diversification in Tourism Cities: Spatial and Economic Outcomes" was presented in IGU DES Ankara Mini Conference, Local and Regional Development in Emerging Economic Geographies, 22-24 October, Ankara, Turkey.

\section{INTRODUCTION}

This paper is about the relation between tourism-firm differentiation and tourism-place differentiation in the sun-sea-sand mass-tourism city of Antalya (Turkey)(2). At first look, sun-sea-sand mass-tourism seems to be at odds with tourism-firm and tourism-place differentiation because mass tourism stands for Fordism: a coherent whole of characteristics that complement each other such as standardization, economies of scale, rationalization, predictability of quality, sellers markets (controlled by international tour-operators), passive consumers, and McDonaldized places whereas tourism-firm and tourism-place differentiation is associated with flexible specialization, that is to say niche markets, small-scale production, economies of scope, quality uncertainty, buyers' markets, active consumers, distinction according to class and life style, and place differentiation (Ioannides and Debbage, 1998; Hiernaux-Nicolas, 2003). However, over the last decade, tourism researchers have argued that mass tourism does not necessarily conflict with tourism-firm differentiation and tourism-place differentiation. First, Vainikka (2013) argues that the mass in mass tourism is not necessarily a homogeneous entity but can be made up of a large number of heterogeneous tourists. Secondly, the Fordist model of tourism production and consumption has become more specialized and flexible while retaining its mass scale, and Fordism and flexible specialization in tourism often co-exist in space and time (Ioannides and Debbage, 2008; Torres, 2002). Thirdly, mass tourism is often accompanied by tourism urbanization (Mullins, 1991), and the export base of many mass-tourism cities is often driven by more industries than only tourism. It is a common wisdom that urban growth is associated with economic diversification (Kemeny and Storper, 2015), which even applies to growing sun-sea-sand tourism cities (Erkuş-Öztürk and Terhorst, 2015), and is associated with spatial differentiation too. Tourism urbanization implies that urban areas are built in different periods of time (with distinct levels of socio-economic development and planning rules), and are simultaneously the outcome
Urban and Regional Planning, Akdeniz University, Antalya, TURKEY.

** Department of Planning, Geography and International Development Studies, University of Amsterdam, Amsterdam, The NETHERLANDS. 
of combined and uneven development. Older and newer (tourism) places simultaneously compete with each other leading to more differentiation. Old buildings in older areas fall into decay before they are renovated, if at all, as a result of which the composition of their populations diverges. In addition, the differentiation of (tourism) firms and types of local and non-local visitors in different places is further stimulated by competition between (tourism) firms in and between different places.

Tourism-firm differentiation in and between tourism places is the outcome of immigration and emigration, new start-ups and closures, and differentiation strategies of incumbent firms. This paper is about the relation between differentiation strategies of incumbent tourism firms (hotels, restaurants, jewellers, and clothing-, shoes-, and bags shops strongly oriented at the tourism market) and tourism-place differentiation in the sun-sea-sand mass-tourism city of Antalya. What is meant by tourism-firm differentiation is the attempts of tourism firms to distinguish themselves from others through innovations and/or renovations of their interior and exterior design (see section 2 how these concepts are operationalized). Tourism firms, like all firms, can follow different competitive strategies to distinguish themselves from other firms, (i) by reducing costs and prices through standardization and economies of scale, (ii) by introducing product innovations and/or producing (higher-quality) goods and services for specific market segments (competing on quality rather than on price), or (iii) by exploiting economies of scope through producing specific combinations of goods and services (diversified firms).

This paper aims to explore whether Antalya's tourism firms follow a more active strategy of differentiation than in some other tourism places. We hypothesize, as will be explained later, first, that hotels in tourism enclaves follow, paradoxically, more actively strategies of differentiation than in other tourism places. Secondly, restaurants, jewellers, and clothing-, shoes-, and bags shops oriented at specific market segments that actively follow a strategy of differentiation are most likely located in (monumental) mixed tourism places visited by tourists and locals. Thirdly, we expect that tourism firms in what we call 'mixed places with weak tourism functions' mainly visited by lower- and lower-middle class locals follow less strategies of differentiation than firms in other tourism places.

This paper is organized as follows. In the first section, the literature on the complex relation between type of firms and types of tourism places is discussed. At the end of this section, the three research hypotheses are explained. The second section explains research design and methodology, whereas in the third one the empirical results of the research are presented.

\section{TOURISM FIRM DIFFERENTIATION AND PLACE DIFFERENTIATION}

Why do tourism firms like other firms attempt to distinguish themselves from others? Schumpeter (1934) argued a long time ago that capitalism is dynamic because entrepreneurs try to escape from cut-throat price competition in fully competitive markets through "new combinations" or innovations (process innovations, product innovations, organizational innovations, the opening of a new market, and the conquest of a new source of supply). Under conditions of monopoly and monopolistic competition, profits are higher compared to fully competitive markets. Schumpeter's ideas have influenced Michael Porter (1990) who argued that 
firms can basically follow two competitive strategies, namely (1) selling standardized goods and services at a mass market against low prices, which are realized through internal economies of scale (in this strategy firms compete primarily on price rather than on quality), or (2) selling specialized goods and services at niche markets, on which firms compete primarily on quality rather than on price. However, Porter (1990) also argues, the first strategy reaches its limits when prices can hardly be cut through process innovations, as is the case in many services industries. That is why in post-industrial economies firms are ever more inclined to follow the second strategy. This idea has also been put forward in the voluminous (non) tourism literature discussing the switch from Fordism to post-Fordism, to which we referred in the introduction.

How is tourism-firm differentiation related to tourism-place differentiation? Places are more or less bounded sites of face-to-face relationships among individuals and/or other forms of direct interaction among social forces. Places are generally closely tied to everyday life, have temporal depth, and are linked to collective memory and social identity. They provide strategically selective social and institutional settings for direct interactions and structure connections beyond that place to other places and spaces (Jessop, 2009, 95). This definition of place obviously includes tourism places, although tourism spaces differ from non-tourism places in three respects: (i) they are visited by a significant number of tourists, (ii) daily life of tourists is much more temporal than that of locals, and/or (iii) tourism services are provided by tourism firms. We would like to stress that places should not be seen as pre-given, pre-modern, static, closed local communities, the specific identity and character of which has been destroyed by globalisation or, in our case, by global tourism. The specificity of places does not only lie in spatial isolation but is the outcome of both local and extra-local interactions (Massey, 2005, 64-71). Nor should places be seen as fully coherent wholes because their potential coherence is undermined by the dynamics of change (Massey, 2005, 36-42).

In most tourism places tourism firms (including semi-public organizations, such as museums) are, along with local inhabitants and local visitors, tourists, property owners, and the (local) state, key actors in the process of place making. It is through the (inter-) actions of these key actors that tourism places are created, and change in course of time. Like other actors in a place, tourism firms and tourism places are mutually related to each other. On the one hand, a tourism place is partly the outcome of the strategic decisions of tourism firms and, on the other hand, their decisions are partly shaped by the specific character of a tourism place. A tourism firm that, without taking into consideration the decisions of other tourism firms, decides to follow a strategy of standardization, to introduce a product innovations, to deliver higher-quality goods for specific market segments or to deliver a specific combination of goods and services will change the character of a tourism place. The more dominant a firm in a place is, the more its character will change. Thus the character of a tourism place can be changed by the strategic decision of even one (dominant) player. Tourism entrepreneurs often make strategic decisions without taking into consideration and anticipating on the decisions of other tourism entrepreneurs. A real entrepreneur does not want to adapt to the decisions of other entrepreneurs but wants them to adapt to him or her. Thus, it is quite possible that all tourism entrepreneurs in a place make their strategic decisions without taking into consideration the decisions of other tourism entrepreneurs with the possible outcome of a highly variegated mix of 
standardised, innovative, and diversified tourism firms. Such a mix may reduce positive externalities as a result of which everybody is worse off. If, for instance, a few firms decide to standardize their goods and services, then the type of visitors and, therefore, the market in the place will change, which forces other firms to adapt to new market conditions. This can have negative effects on the tourism firms that had decided to orient themselves to specific market segments. It is difficult for a restaurant to become an innovative Michelin-starred restaurant in a tourism area dominated by low-budget hotels, unless it has already built up a good reputation among locals. In short, tourism entrepreneurs face the following collective action problem. All are better off with positive externalities by means of collective action whereas each believes (s)he is best off with his or her own strategic decision, taken independently from that of others. This collective action problem can hardly be solved in a dynamic economy, although planners and developers sometimes succeed to generate positive externalities and reduce negative externalities through spatial planning. Teller and Schnedlitz (2012), for instance, show that the performance of retailers in planned shopping centres is better than non-planned shopping streets.

The character of a tourism place is not only the outcome of the individual and strategic interactions of tourism firms but also the result of the individual and strategic interactions of all actors involved: non-tourism firms, local inhabitants and local visitors, tourists, property owners, and the (local) state. If for instance, a coalition of local inhabitants and local government succeeds to freeze the building- and street-pattern structure of a monumental tourism place, then it becomes difficult for hotel owners to build big hotels with a diversified supply of services. The building sites are simply too small.

If all actors are taken into consideration, one cannot say that all actors face a collective action problem because it is impossible to say when all actors are best off. The specific character of a tourism place is then the result of power relations between all actors. If, in the famous terms of Albert Hirschmann (1970), the voice of tourism entrepreneurs is too weak to get their aims realized, then they have no other choice than to adapt themselves to the given power relations (loyalty) or to move out to another area (exit). Because the specific character of tourism places is the outcome of the power-laden interactions of all actors involved, tourism places, like all places, have emergent properties, by which is meant "situations in which the conjunction of two or more features or aspects gives rise to new phenomena, which have properties which are irreducible to those of their constituents, even though the latter are necessary for their existence" (Sayer, 2000,12). It is because of these emergent properties of tourism places that one can say tourism places shape decisions of tourism entrepreneurs. Otherwise one runs the risk of saying that decisions of tourism entrepreneurs who co-make tourism places are partly shaped by themselves (which is nonsense, of course). In studies on the relation between neighbourhood characteristics and strategies and performance of firms, so-called neighbourhood effects (the effect of the neighbourhood context on the performance of firms after controlling for firm characteristics) are distinguished from composition effects (the effects of firm characteristics on their performance) but, surprisingly, neighbourhoods are never interpreted in terms of emergent properties (Sleutjes and Schutjens, 2013). 


\section{SUN-SEA-SAND TOURISM CITY OF ANTALYA}

Figure 1. Types of agglomeration economies to the firm (Parr, 2002, 154)

\begin{tabular}{|l|l|l|}
\hline & Spatial Constrained Economies & Spatially Constrained Economies \\
\hline Dimension & Internal & External \\
\hline Scale & $\begin{array}{l}\text { Economies of Scale (Horizontal } \\
\text { Integration) }\end{array}$ & Localization Economies \\
\hline Scope & $\begin{array}{l}\text { Economies of Scope (Lateral } \\
\text { Integration) }\end{array}$ & Urbanization Economies \\
\hline Complicity & $\begin{array}{l}\text { Economies of Complicity } \\
\text { (Vertical Integration) }\end{array}$ & Activity-Complex Economies \\
\hline
\end{tabular}

Tourism places are, when we focus on (tourism) firms and ignore (power) strategies of other actors, the results of agglomeration economies. In economic-geography literature, different types of agglomeration economies are distinguished. In Figure 1 spatially-constrained internal economies and external economies are distinguished on the horizontal axis and scale, scope and complexity on the vertical axis.

Tourism places are partly the result of internal economies of scale. The kitchen and the service in a restaurant, for instance, have to be integrated in one establishment. Note, however, that internal economies of scale can be realized at a wider spatial scale as in the case of a multiplant firm at different locations (McDonalds, for instance). The internal economies of scale of multi-plant firms are often based on lower costs of management and R\&D as well as the benefits of a brand name. Spatially clustered tourism firms that belong to the same industry such as hotels or restaurants can also benefit from external economies of scale because of the availability of a specialized labour market, a concentration of specialized suppliers, public goods specific for firms within a particular industry, and knowledge spill-overs that are very important for product and process innovations. In economic geography literature it is widely argued that industrial districts of firms that belong to the same industry can be very innovative (Malmberg and Maskell, 2002). The same applies to literature on tourism and hospitality (see for hotels Erkuş-Öztürk (2009), and for restaurants Ottenbacher and Harrington (2007). The spatial scale of these external economies is also highly variable, and is often much wider than that of tourism places in a city. The spatial scale of the labour market, the availability of specialized suppliers, and knowledge spill-overs mostly stretches beyond the boundaries of a tourism place (Bathelt et al., 2004). Spatial planning (a public good) on behalf of a specific tourism industry such as hotels (most tourism resorts are dominated by hotels) is the exception to the rule. However, there are urban tourism places that are dominated by localization economies. Birmingham's jewellery district is an industrial district in the city in which a few hundred of jewellery producers are concentrated, which has become a tourist attraction (De Propris and Lazzeretti, 2007). In Antalya there is no such case.

In case of internal economies of scope, tourism firms benefit from the delivery of different types of services, such as a hotel- and restaurant services within the same building. But just as in the case of internal economies of scale, internal economies of scope in multi-product firms are often realized at a very broad spatial scale. External economies of scope are called urbanization economies, like for instance firms of different industries benefit from clustering because of the specific demand in a place (lowbudget hotels and standardised restaurants, for instance, mutually benefit from being co-located in a tourism place), the availability of a labour force 
that can be employed in different industries, the availability of public goods beneficial to all industries, and inter-industry spill-overs (Jacobs, 1969), on condition that the cognitive distance between industries is low (Frenken and Boschma, 2007).

The dimension complexity is less discussed in the literature and is probably less relevant in our case. Whereas scope is concerned with the multi-product nature of the output, the dimension of complexity refers to multi-input nature of production and, more generally, to the fact that a firm's production involves several technologically separable stages. When such a complexity exists within a firm, the structure is usually referred to as vertical integration. Some restaurants have their own vegetables and herbs garden to have extremely fresh ingredients for their dishes, and some hotels have their own transportation services or are owned by a tour operator with its own airline company. In case of spatially constrained external economies of complexity we speak of activity complex economies.

The above-given typology is useful in the sense that different types of agglomeration economies are distinguished in a systematic way but its weak point is that it is a supply-side typology. It largely ignores the positive externalities of firms that are oriented to the same type of market segment. Owners of different luxurious shops prefer to be clustered because they mutually benefit from their common clientele.

From above-given typology, it is clear that in case of urbanization economies (external economies of scope) a mix of firms that belong to different (tourism- and non-tourism industries) mutually benefit from each other. However, some tourism firms do not want and/or cannot be dependent on external economies of scope (urbanization economies). Big hotels that offer a large variety of services do not want to be dependent on external economies because they aim to make extra profits by internalizing externalities and/or are forced to diversify because they are located in a very homogeneous tourism area being isolated from the city. Our first hypothesis is that hotels in tourism enclaves follow, paradoxically, more actively strategies of differentiation than in other tourism places. Those enclaves, which are the antipodes to Jane Jacobs' (1961) mixed urban neighbourhoods, are dominated by 5-star hotels, which are generally (wherever they are located) more innovative than lower-quality hotels (Erkuş-Őztürk, 2016). In addition, those hotels are forced to follow a strategy of diversification because they cannot benefit from external economies of scope.

Our second hypothesis is that mixed places that are visited by both locals and tourists (historical diversified tourism places and mixed places with strong tourism functions) are the most favourable environment for innovative and renovating restaurants and shops that sell (high-quality) goods and services to specific market segments. This hypothesis is based on research on restaurants in Amsterdam and Antalya (Terhorst and Erkuş-Öztürk, 2015; Erkuş-Öztürk and Terhorst, 2016) but is applicable for other types of tourism firms too. They found that Amsterdam restaurants predominantly visited by foreign tourists are of lower quality than restaurants predominantly visited by locals, and that most innovative restaurants in Antalya are visited by a mix of locals and foreign tourists (Terhorst \& Erkuş-Öztürk, 2015; Erkuş-Öztürk and Terhorst, 2016). Their explanation is grounded in the so-called demand-pull theory of innovation, (which goes back to Adam Smith) (Schmookler, 1966), which says that fast growing industries and firms are more innovative than slow growing ones. 
If growth of tourist visitors is much higher than the growth of the local visitors, then one would, according to that theory, expect that restaurants predominantly oriented to tourists are more innovative than restaurants predominantly oriented to locals. However, tourism market is a seasonal market with a high (and often yearly growing) demand during the season and a low demand in the off-season. That is why restaurants that are visited by a mix of locals and tourists are in a favourable position. They are visited all year by (a growing number of) locals and take advantage of the growth of the tourism market in the high season. Thus the less volatile growth of restaurants visited by a mix of locals and tourists is the most favourable condition for innovations. In addition, most of the restaurateurs and chefs in tourism places know the local and national quality standards of the dominant national kitchen as well as the local and national culinary fashions much better than foreign ones. Given the fact that culinary innovations are based on culinary traditions -they do not fall from heaven (Rao et al, 2003), chefs and restaurateurs of restaurants visited by locals are less uncertain to introduce innovations than restaurants visited by foreign tourists only (Erkuş-Öztürk and Terhorst, 2016).

Our third hypothesis is about mixed tourism places with weak tourism functions, and is related to our second hypothesis. In the literature it is shown that high-quality hotels and restaurants are more innovative than lower-quality ones (see for hotels Erkuş-Ôztürk, 2016, and for restaurants (Erkuş-Öztürk and Terhorst, 2016; Rao et al, 2003; Ottenbacher and Harrington, 2008; Svejenova et al., 2007). But high-quality services obviously are more expensive than lower-quality ones and are mainly consumed by higher-middle and higher classes, which implies that firms in tourism places with weak tourism functions predominantly visited by lower and lower-middle classes such as Antalya centre are less innovative and make less renovations than firms in other tourism places.

\section{DESIGN OF THE CASE STUDY AND METHODOLOGY}

Over the last twenty years, tourism has boomed in the province of Antalya. Its number of visitors has grown from 1 million in 2000 to about 10 million in 2016. Antalya's tourism is almost entirely dominated by foreign visitors. Around $95 \%$ of all of its visitors come from abroad, particularly from Germany, Russia, Ukraine and the Netherlands (Ministry of Culture and Tourism, Department of the Province of Antalya, 2011). The region has become the second most important tourist region of Turkey (after Istanbul) and is one of the leading mass-tourism regions of the Mediterranean Sea. This turbulent development has resulted in rapid tourism urbanization along the coast of the province of Antalya.

To define the sample, population data of firms (hotels, restaurants, jewellers, and clothing-shoes-, and bags shops) were obtained from a)

\begin{tabular}{|c|c|c|c|c|}
\hline Companies & Population (N) & $\begin{array}{l}\text { Sampling size } \\
\text { (n) }\end{array}$ & Error (z) & $\begin{array}{l}\text { Distribution } \\
\text { rate }\end{array}$ \\
\hline Hotels & 62 & 35 & 0,1102 & 0.5 \\
\hline Restaurants & 152 & 54 & 0,1074 & 0.5 \\
\hline Jewellery Companies & 126 & 46 & 0,1155 & 0.5 \\
\hline $\begin{array}{l}\text { Retail Trade Companies (Carpet, leather, shoe, textile } \\
\text { selling) }\end{array}$ & 238 & 50 & 0,123437 & 0.5 \\
\hline Total n: 185 & & & & \\
\hline
\end{tabular}


Ministry of Culture and Tourism, b) Antalya Province Culture and Tourism Head Office, c) Antalya Jewelry Association and d) Antalya Industry and Trade Association (ATSO) between January and March 2014.

The population of tourism companies from across different urban tourism areas in Antalya city centre is 578. A stratified sample of 185 companies was drawn on the basis type of company and location along the coast. These 185 companies were interviewed with a questionnaire that included dichotomous, open-ended as well as multiple-choice questions between January and March 2014. The confidence level is 95 (see Table 1). The first part of the questionnaire for all companies consisted of questions about characteristics of firms (such as size of company, type of company, branch offices, investments in related and unrelated sectors, number of employees, education level of employees, background of employees and any collaborations with other restaurants), and its location (quiet streets, passer-by streets, touristic streets). The remaining part contained questions on types of consumers (tourists, locals), and strategies of differentiation and innovation (such as types of dishes served, types of consumers, assets points of attraction, increase in physical capacity, new products and services, type of advertisements, discounts, R\&D services, thematic changes, target groups, new markets, service quality, employee uniforms, specific services for tourists, innovative services to tourists and locals, innovative products and services developed over the last 3 years).

After having done the interviews, quantitative multivariate techniques, namely a shared cross-tables, chi-squares and correspondence analyses were applied to clarify any association between variables. While a chisquare analysis shows the significance of any relationships between variables, a correspondence analysis provides another insight, showing their association in terms of their distances from each other on a bi-plot. This is a grouping technique that differs from other interdependence techniques in its ability to accommodate both non-metric and nonlinear relationships. A correspondence analysis utilizes the coordinates on a bi-plot, which is the basic outcome of the analysis, showing the correspondence between the items in two basic categories in terms of their distance from each other (Beyhan, 2006). To increase the perceptibility of groupings in bi-pilot of the correspondence analysis, different colours (black and grey) and figures (square and circle) are applied to the items from each category. In bi-plot of the correspondence analysis, categories perceived as similar are located close to one another, while in a graphical portrayal (bi-plot), variables are located closer to the categories with which they are most strongly associated, and are further from the categories with which they have lower associations.

After having collected the data, level of differentiation of interviewed tourism firms was defined by asking the interviewees about any new arrangements, modifications, improvements and innovations in the products and services they offer. Examples of "soft" innovations include: giving surprise gifts to customers on their birthdays, honeymoons (surprise gifts in the rooms, birthday cakes, live music); surprise services and meals given to guests on special days, national days, holy days; branded gifts, such as socks; organic meals; organic toiletries; planting a tree in the garden of the hotel for repeat customers with their names attached; private call buttons in their rooms and by their sunbeds; special apps in the gym and on beaches; special cameras at each table allowing children in the playground to be monitored; special tablet menus; small flags put on meals 


\section{SUN-SEA-SAND TOURISM CITY OF ANTALYA}

Figure 2. Spatial distribution of standardized and differentiated tourism firms

$0=$ standardized firms, $1=$ slightly differentiated firms, $2=$ differentiated firms, $3=$ strongly differentiated firms

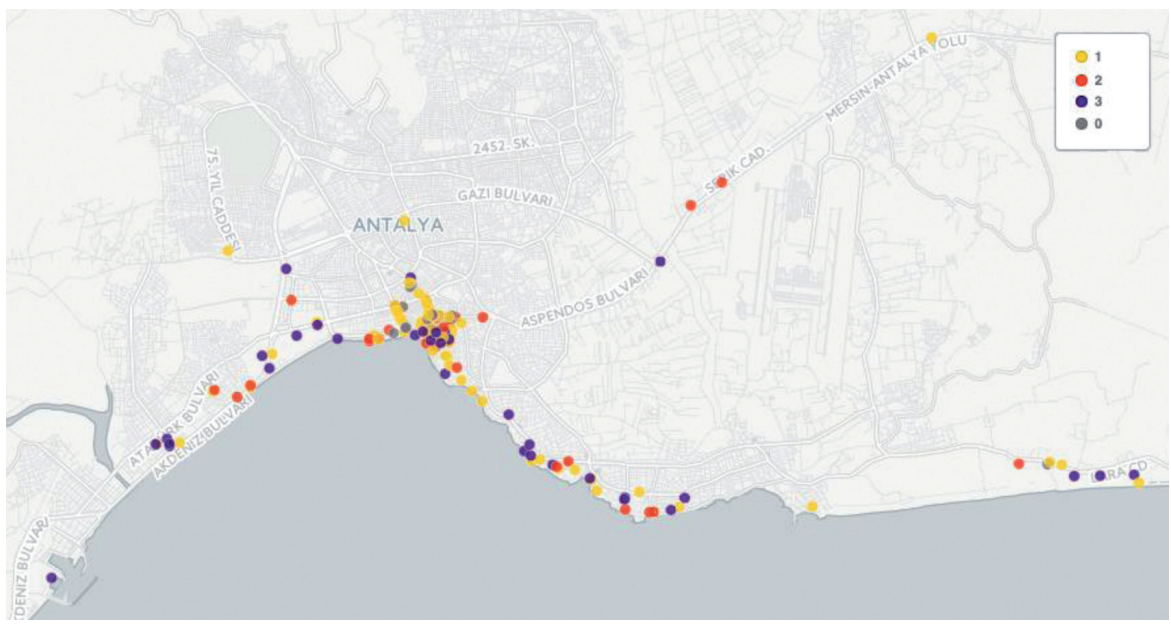

carrying restaurant advertisements; VIP lounges; wooden menus; special karaoke rooms for guests; a large aquarium as an interior design feature; cartoon shows and special care for children; a footman on each floor; private designs for each person; dishes prepared in a molecular kitchen; meat dried in a special meat drier; fine-dining concepts; invitations to Michelin-starred chefs; new combinations of creative dishes that are unique to Antalya; a fusion kitchen combining different international cuisines; dishes made with ecological ingredients; specially made sauces; and a sousvide cooking system, as seen in Michelin-starred restaurants. Examples of other type of differentiation, referred to as renovations in this article, include new building interiors and/or exteriors, new furniture, freshly painted walls and floors with new designs, new landscape designs around the building, construction of child entertainment areas, and new terraces. All of these factors were used by the interviewee's to define their level of differentiation.

Tourism firms that did not make any change in their products or services are referred to as standardized firms. Firms that made one or two (small) renovations in interior and/or exterior design are referred to as slightly differentiated firms. The firms that made 3-4 product/service innovations are referred to as differentiated firms, and the ones that made 5 or more product/service innovations are referred to as strongly differentiated firms. The spatial distribution of all those firms in Antalya's tourism zone is shown in Figure 2.

In the third step, four different tourism places in Antalya were distinguished according to their different mix of functions, namely (i) homogeneous tourism places (HOTP's), (ii) a historically diversified tourism place (HDTP), (iii) mixed places with strong tourism functions (MPSTF's), and (iv) mixed places with weak tourism functions (MPWTF's). Cross-tabulation tables and correspondence analyses are applied to analyse the association between types of tourism places and tourism-firm differentiation.

Homogenous tourism places refer to special tourism enclaves that have mainly only one or two tourism functions, such as, for instance, Kundu tourism centre. These tourism centres have been created and planned by the Ministry of Culture and Tourism in collaboration with business (infrastructure) associations created by central state to stimulate the development of mass tourism. In development plans, investors could 
Table 2. Relation between level of tourismdifferentiation and different types of urban tourism places

0: standardized firms, 1: slightly differentiated firms, 2: differentiated firms, 3: strongly differentiated firms. HOTP's: homogeneous tourism places, HDTP: historical diversified tourism place, $\mathrm{MPSTF}^{\prime}$ : mixed places with strong tourism functions, MPWTF's: mixed places with weak tourism functions. only buy large plots of land as a result of which tourism centres are dominated by big, mainly 5-star, hotels. These tourism enclaves are very much segregated from daily life of the city centre, and have only a few urban functions. As the dominant 5-star hotels have internalized most services, one can find here only some small shopping malls (in bazaar-like buildings) in which clothes, shoes, bags, watches and jewels are sold to guests of the nearby 5-star hotels. Another homogeneous tourism area is the main road to the airport, which is dominated by big jewellery shops to which the guests of big hotels are channelled by tour guides.

The historical diversified tourism place, the Kaleiçi port area with a lot of monumental Ottoman buildings, contains a variegated mix of small companies that are related to the tourism sector either directly or indirectly, such as restaurants, small hotels, jewellers, souvenir shops, and shops selling clothes, shoes and bags mainly to foreign tourists. Due to the small size of those tourism firms, this place is not dominated by mass-tourism.

Mixed places with strong tourism functions refer to mixed places in which tourism functions dominates all other functions. In these places, one can find 5-star hotels, and restaurants visited by tourists, businessmen and locals, shopping malls visited by tourists and locals alike, residential areas, coffee shops, some entertainment, and cultural and green parks near the coast. Konyaalti-West and Konyaalti-East are the examples of such mixed places.

Mixed places with weak tourism functions refer to places that are dominated by businesses and housing, some restaurants predominantly visited by locals, and some tourism functions such as medium-sized hotels scattered throughout the place. In these places tourism functions are secondary or less dominant than in other places. Antalya city-centre and the Lara coastal district are good examples of them.

\section{MAIN FINDINGS}

To examine the research hypotheses, the relation between level of tourism firm differentiation and types of tourism places is first explored for all firms. Then hotels, restaurants, jewellers, and clothing-, shoes, and bags shops are analysed separately. For all firms in the sample, chi-square results (chi-square: 21.641, significant at 0.01 level) reveal a significant difference between level of tourism firm differentiation and types of tourism places.

When level of differentiation of tourism firms is cross-tabulated with different types of tourism places (Table 2), it is remarkable that most

\begin{tabular}{|c|c|c|c|c|c|c|c|}
\hline $\begin{array}{l}\text { Tourism places/ } \\
\text { Differentiation Le }\end{array}$ & HOTP's & HDTP & MPSTF's & MPWTF's & Total & Chi square & p-value \\
\hline 0 & $1(9 \%)$ & $1(3 \%)$ & $3(8 \%)$ & $17(16 \%)$ & $22(12 \%)$ & 0.01 & 21.641 \\
\hline 1 & $3(27 \%)$ & $9(31 \%)$ & 15(39\%) & $58(55 \%)$ & $85(46 \%)$ & & \\
\hline 2 & $3(27 \%)$ & $9(31 \%)$ & $6(16 \%)$ & $17(16 \%)$ & $35(19 \%)$ & & \\
\hline 3 & $4(37 \%)$ & $10(35 \%)$ & $14(37 \%)$ & $14(13 \%)$ & $42(23 \%)$ & & \\
\hline Total & $11(100 \%)$ & $29(100 \%$ & $38(100 \%$ & $106(100 \%)$ & $184(100 \%)$ & & \\
\hline
\end{tabular}


Figure 3. Relation between level of differentiation of firms and different types of urban tourism places

Rows: 0 : standardised firms, 1 : slightly differentiated firms, 2: differentiated firms, 3: strongly differentiated firms. Columns: HOTP's: homogeneous tourism places, HDTP: historical diversified tourism place, MTPSF's: mixed places with strong tourism functions, MPWTF's: mixed places with weak tourism functions.

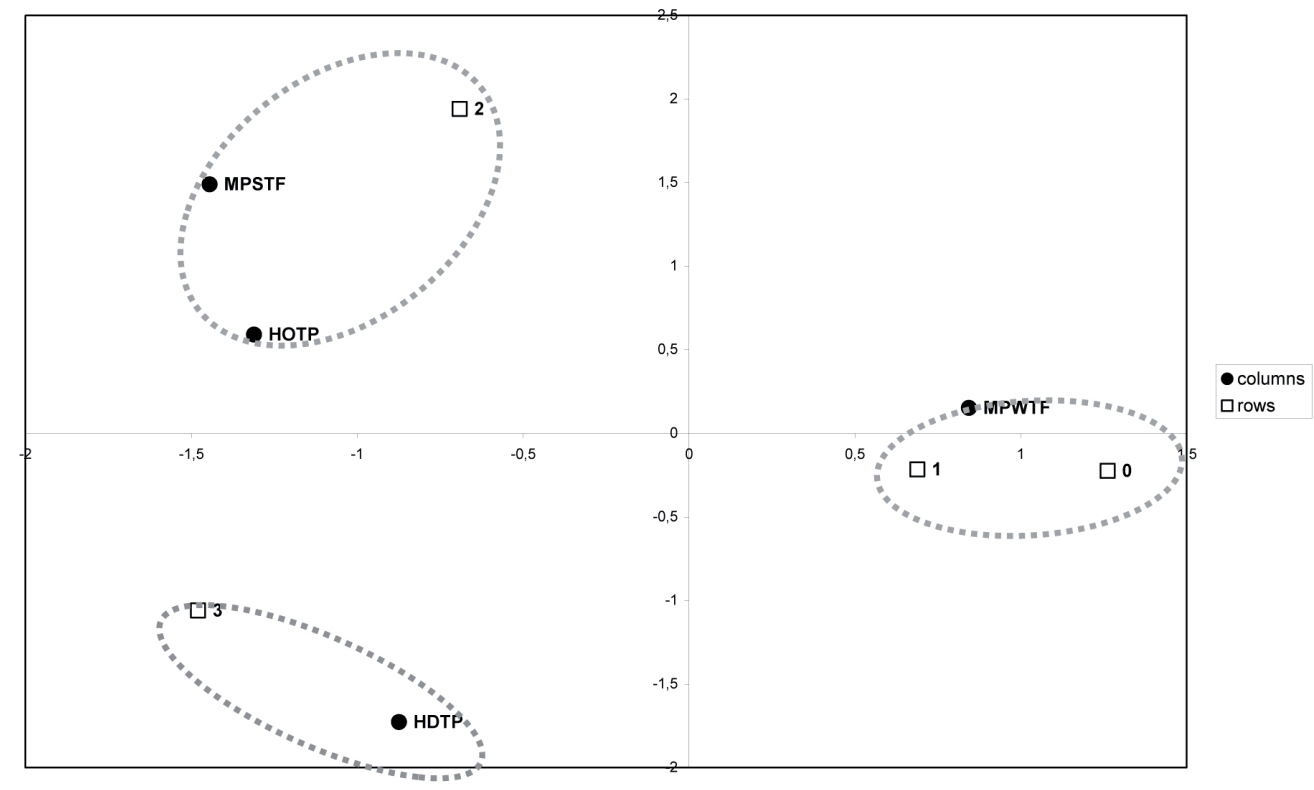

tourism firms (64\%) in homogeneous tourism places follow a fairly active strategy to differentiate their products and/or services. Only $9 \%$ of tourism firms did not realize any differentiation at all (standardized companies) whereas $27 \%$ of them hardly did (slightly differentiated firms).

A close inspection of the interview data reveals that differentiated firms in homogeneous tourism places are mainly big, 5-star hotels in tourism zones. However, standardized firms in homogeneous tourism zones, by contrast, are shops (except jewellers) which are located in small shopping malls (in bazaar-like buildings) which sell their goods only to tourists staying in 5 -star hotels in the same place.

The correspondence bi-plot (Figure 3) also points to a strong association between the historical diversified tourism place and firms with a high level of differentiation. According to Jane Jacobs (1961), such mixed urban places are attractive to local inhabitants/visitors and tourists, and are breeding grounds for innovative firms. Tourism firms in particularly this place benefit from external economies of scope.

The highest share of standardized and slightly differentiated firms (16\% and $55 \%$ respectively) is located in mixed places with weak tourism functions. This relation is confirmed in correspondence-analysis bi-plot that shows a strong association between standardized firms and mixed places with weak tourism functions. It seems that tourism places in places that are not very much visited by tourists do not feel a strong pressure to differentiate their products and/or services (Figure 3).

\section{Level of Differentiation of Hotels in Different Types of Tourism Places}

Hotels generally are very active in differentiating their products and services. The total number of differentiated and strongly differentiated hotels (19) is larger than the number of slightly differentiated hotels (15) whereas there are no standardized hotels in the sample. In accordance with our second hypothesis, hotels in homogeneous tourism places follow very actively strategies of differentiation of their products and services, as is shown in Table 3 and in the results of the correspondence analysis 
Table 3. Relation between level differentiation of hotels and urban tourism places.

0: standardised hotels, 1 : slightly differentiated hotels 2: differentiated hotels, 3: strongly differentiated hotels (5 and more diversified products). HOTP's: homogeneous tourism places, HDTP: historical diversified tourism place, MPSTF's: mixed places with strong tourism functions, MPWTF's: mixed places with weak tourism functions.

\begin{tabular}{lllll}
\hline Level of differentiation & $\mathbf{1}$ & $\mathbf{2}$ & $\mathbf{3}$ & Grand Total \\
\hline HOTP'S & $1(20 \%)$ & $1(20 \%)$ & $3(60 \%)$ & $5(100 \%)$ \\
HDTP & $5(56 \%)$ & $1(11 \%)$ & $3(33 \%)$ & $9(100 \%)$ \\
MPSTF'S & $4(33 \%)$ & $5(42 \%)$ & $3(25 \%)$ & $12(100 \%)$ \\
MPWTF'S & $5(62,5 \%)$ & $2(25 \%)$ & $1(12,5)$ & $8(100 \%)$ \\
\hline Grand Total & $15(44 \%)$ & $9(27 \%)$ & $10(29 \%)$ & $34(100 \%)$ \\
\hline
\end{tabular}

Figure 4. Relation between level of differentiation of hotels and types of tourism places

Rows: 0: standardized hotels, 1 : slightly differentiated hotels, 2: differentiated hotels, 3: strongly differentiated hotels. Columns: HOTP's: homogeneous tourism places, HDTP: historical diversified tourism places, MPSTF's: mixed places with strong tourism functions, MPWTF's: mixed places with weak tourism functions.

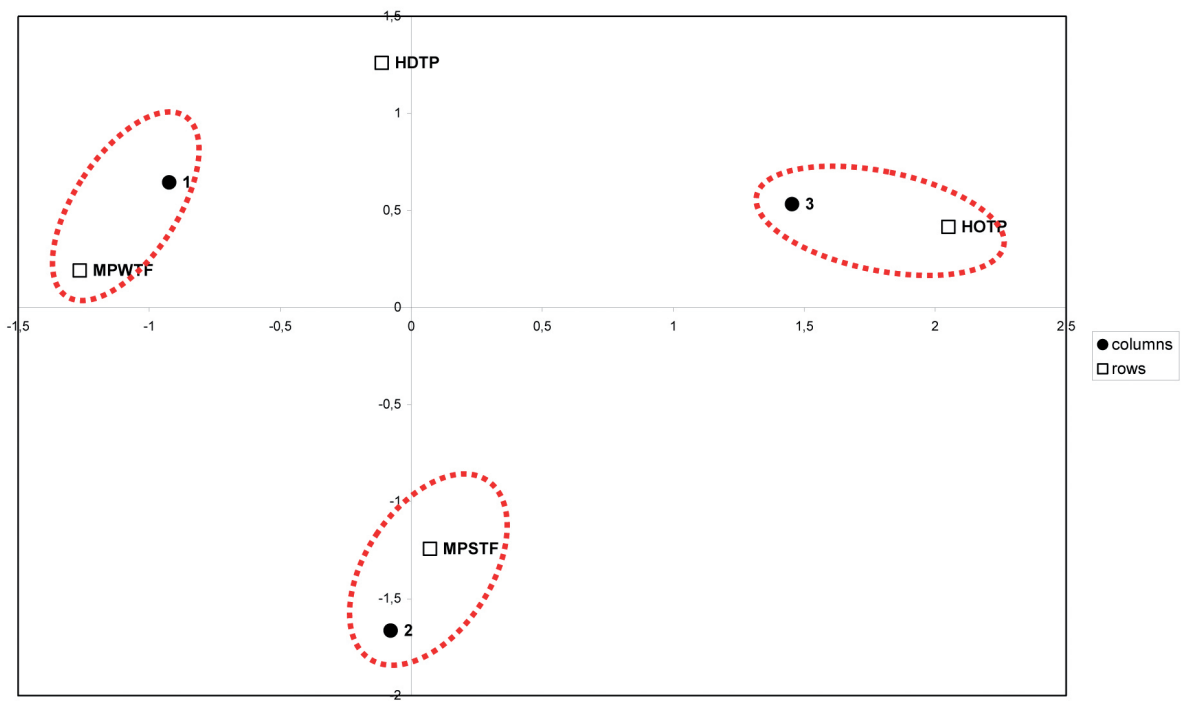

(Figure 4). As said before, these places are dominated by big, 5-star hotels that generally are more innovative than lower-quality hotels, and these hotels offer a wide range of goods and services because they cannot benefit from external economies scope there.

Hotels in mixed places with weak tourism functions and in historically diversified tourism places are the least active in differentiating their products and services. No less than $62.5 \%$ of the hotels in former area and $56 \%$ in the latter made only a few modifications in their products and services (Table 3). The low level of differentiation in mixed places with weak tourism functions is related with both the medium size of their hotels and the specific character of these places. They have low tourism functions and their hotels are hardly visited by foreign tourists. The low level of differentiation in Kaleiçi port area with protected monumental buildings is related with small size of the buildings that offer room to small standardized hotels only and some boutique hotels (boutique hotels generally are more differentiated than other small hotels in the area but their absolute number is relatively small).

\section{Level of Differentiation Of Restaurants In Different Types Of Tourism Places}

In homogeneous tourism places there are no independent restaurants because tourism enclaves in urban periphery are fully dominated by big all-inclusive hotels. No independent restaurant can economically survive in such places. That is why these places are excluded from the analysis. 


\section{SUN-SEA-SAND TOURISM CITY OF ANTALYA}

Table 4. Relation between level of differentiation of restaurants and types of tourism places

1: slightly differentiated restaurants, 2 : differentiated restaurants, 3: strongly differentiated restaurants. HOTP's: homogeneous tourism places, HDTP: historical diversified tourism places, MPSTF's: mixed places with strong tourism functions, MPWTF's: mixed places with weak tourism functions.

\begin{tabular}{lllll}
\hline $\begin{array}{l}\text { Level of differentiation/ } \\
\text { Tourism Places }\end{array}$ & $\mathbf{1}$ & $\mathbf{2}$ & $\mathbf{3}$ & Grand Total \\
\hline MPSF's & $5(33 \%)$ & $3(20 \%)$ & $7(47 \%)$ & $15(100 \%)$ \\
HDTP & $3(25 \%)$ & $2(17 \%)$ & $7(58 \%)$ & $12(100 \%)$ \\
MPWTF's & $10(37 \%)$ & $6(22 \%)$ & $11(41 \%)$ & $27(100 \%)$ \\
\hline Grand Total & $18(33 \%)$ & $11(20 \%)$ & $25(46 \%)$ & $54(100 \%)$ \\
\hline
\end{tabular}

The highest share of all restaurants (27 of a total of 54 restaurants) is located in mixed places with weak tourism functions. Restaurants in these places are the least active in differentiating their products and services. They only made some renovations (Table 4). This is confirmed in bi-plot of the correspondence analysis. Figure 5 shows a strong association between restaurants that only made renovations and mixed places with weak tourism functions. Next to this strong association, the correspondence bi-plot shows a slight association between level of differentiation of restaurants and the Kaleiçi port area (Figure 5). Due to small size of its historic buildings, restaurants in this place can hardly benefit from economies of scale, and the market in this place is favourable to innovative restaurants. These places attract many foreign and national tourists as well as businessmen and (rich) locals. This result is in accordance with hypothesis 2 which says that restaurants visited by a mix of locals and tourists have, compared to restaurants visited by either locals or tourists only, the advantage of a stable or steadily growing demand of locals and a peak demand of tourists during high season. Because generally a (steady) growth of the market stimulates firms to innovate, as the demand-pull theory of innovations says, restaurants visited by a mix of locals and tourists are in a more favourable position to innovate than restaurants visited by locals or tourists.

\section{Level of Differentiation of Jewellers and Types of Tourism Places}

Jewellers generally are not very active to introduce new products and/ or services. No less than $22 \%$ and $41 \%$ are standardized and slightly differentiated respectively (Table 5). Thus 63\% of all jewellers did not or

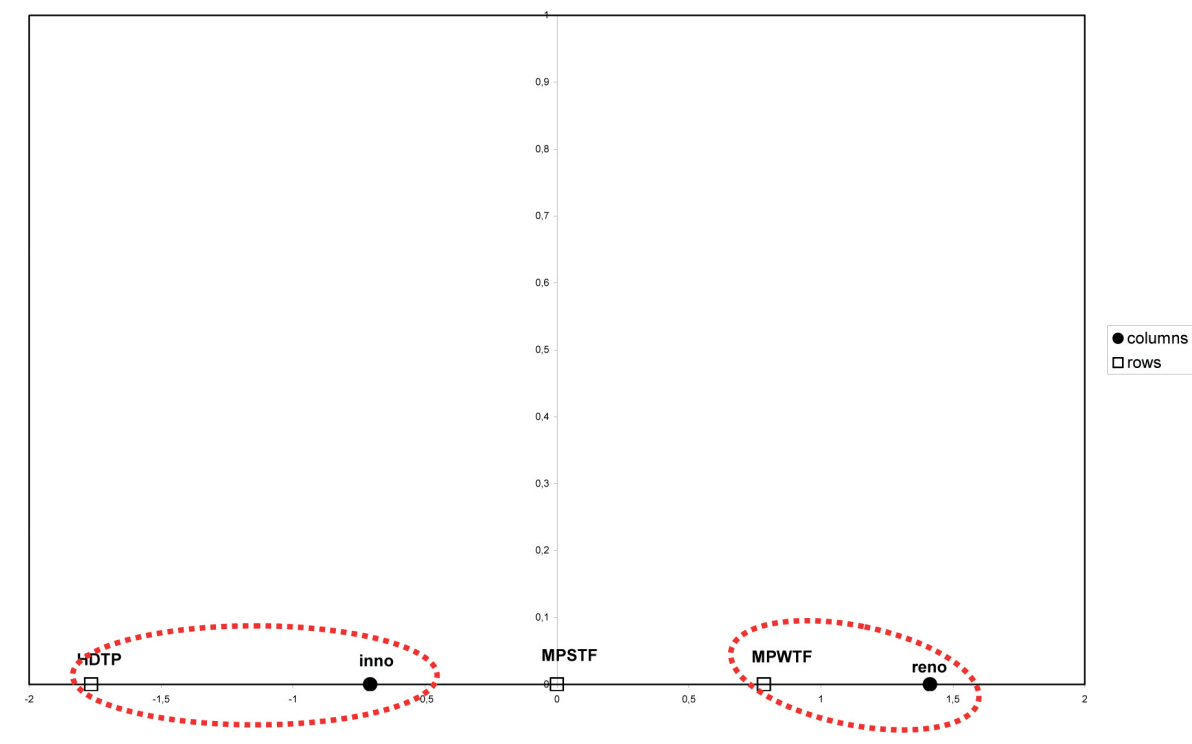

Figure 5. Relation between level of differentiation of restaurants and types of tourism places

Rows: Inno: Innovation of restaurants; reno: renovations of restaurants. Columns: HOTP's: homogeneous tourism places, HDTP: historical diversified tourism place, MPSTF's: mixed places with strong tourism functions, MPWTF's: mixed places with weak tourism functions. 
Table 5. Relation between level of differentiation of jewellers and types of tourism places

Rows: 0: standardised jewellers, 1: slightly differentiated jewellers, 2: differentiated jewellers, 3: strongly differentiated jewellers. Columns: HOTP's: homogeneous tourism places, HDTP: historical diversified tourism place, MPSTF's: mixed places with strong tourism functions, MPWTF's: mixed places with weak tourism functions.

Figure 6. Relation between level of differentiation between jewellers and types of tourism places

Rows: 0: standardised jewellers, 1: slightly differentiated jewellers, 2: differentiated jewellers, 3: strongly differentiated jewellers. Columns: HOTP's: homogeneous tourism places, HDTP: historical diversified tourism place, MPSTF's: mixed places with strong tourism functions, MPWTF's: mixed places with weak tourism functions.

\begin{tabular}{llllll}
\hline $\begin{array}{l}\text { Homogenization level/ } \\
\text { Tourism Places }\end{array}$ & $\mathbf{0}$ & $\mathbf{1}$ & $\mathbf{2}$ & $\mathbf{3}$ & Total \\
\hline MPSF's & $0(0 \%)$ & $0(0 \%)$ & $1(100 \%)$ & $0(0 \%)$ & $1(100 \%)$ \\
HOTP's & $0(0 \%)$ & $0(0 \%)$ & $2(67 \%)$ & $1(33 \%)$ & $3(100 \%)$ \\
HDTP & $3(27 \%)$ & $4(37 \%)$ & $2(18 \%)$ & $2(18 \%)$ & $11(100 \%)$ \\
MPWTF's & $7(23 \%)$ & $15(48 \%)$ & $7(22,5 \%)$ & $2(6,5 \%)$ & $31(100 \%)$ \\
\hline Grand Total & $10(22 \%)$ & $19(41 \%)$ & $12(26 \%)$ & $5(11 \%)$ & $46(100 \%)$ \\
\hline
\end{tabular}
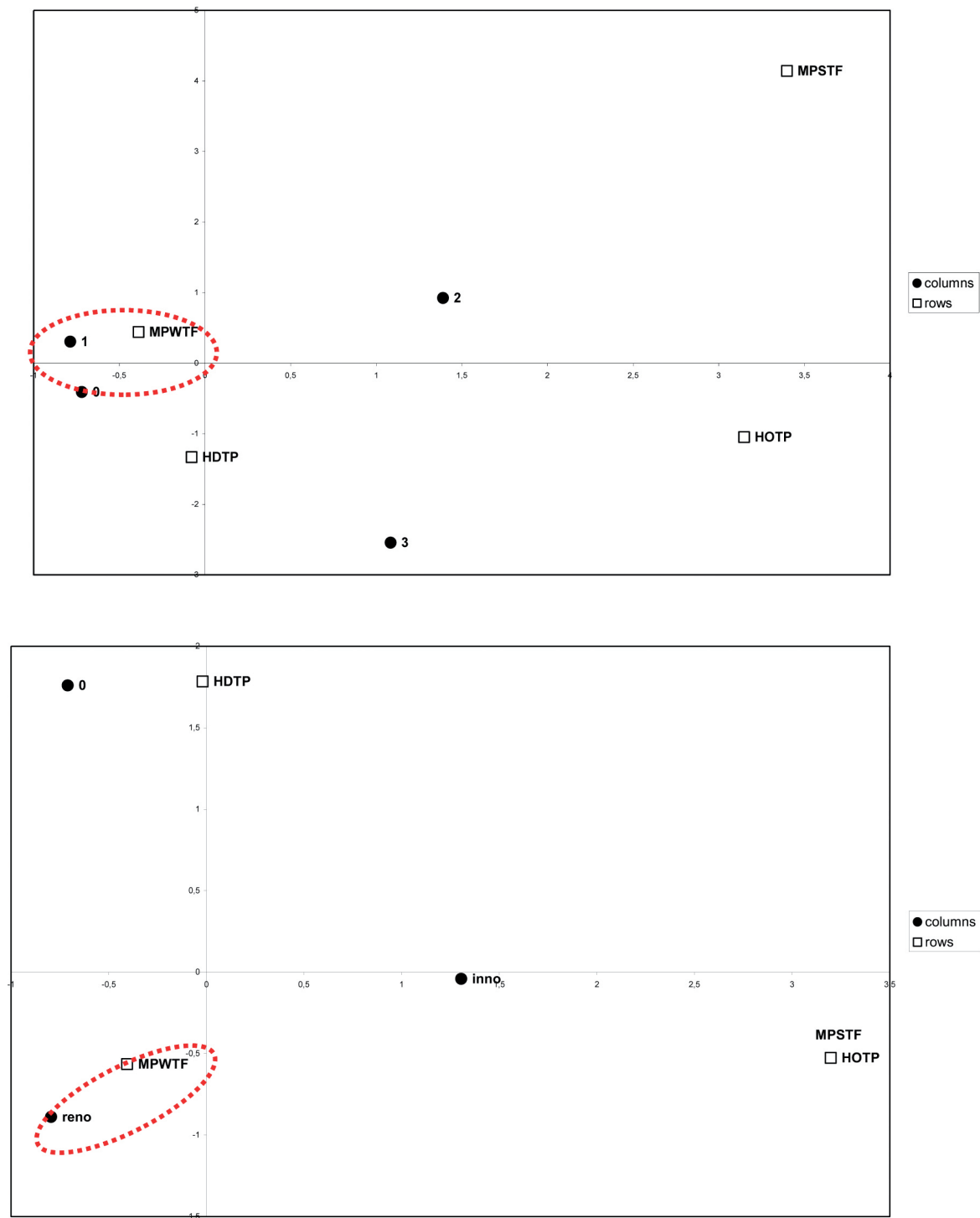

hardly introduce new products and/or services. Most of these standardized $(23 \%)$ and slightly differentiated jewellers $(48 \%)$ are found in mixed places with weak tourism functions. This is confirmed by the results of the correspondence analysis. The bi-plot in figure 4 shows a strong association between standardized jewellers and these places. 
Figure 8. An example of big jewellery shops on the airport highway, Hadrian Jewellery Company
Table 6. Relation between level of differentiation of clothing- and leather shops and urban tourism places

0 : standardized shops, 1 : slightly differentiated shops, 2: differentiated shops, 3: strongly differentiated shops. HOTP's: homogeneous tourism places, HDTP: historical diversified tourism place, MPSTF's: mixed places with strong tourism functions, MPWTF's: mixed places with weak tourism functions.

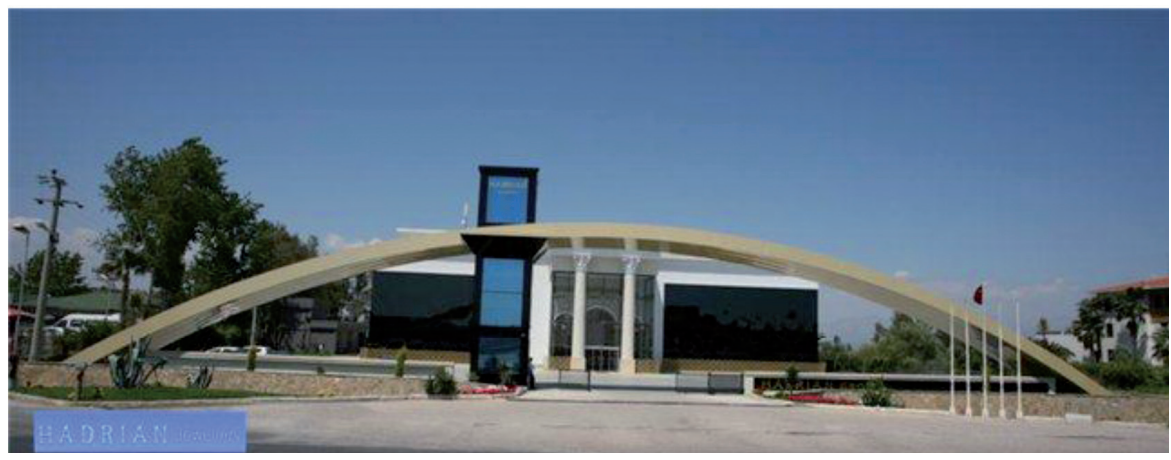

The level of differentiation of jewellers in historically diversified places is also very low: $27 \%$ of them are standardized and $37 \%$ are only slightly differentiated (in total 64\%). This is confirmed in bi-plot of the correspondence analysis (Figure 6, Figure 7). The low level of differentiation in both places is partly explained by dominance of local visitors to both places. In addition, interviewed jewellers in Kaleiçi port area, and in historically diversified tourism places, argue that their market share of specialized jewels is on decline in favour of the big jewellery shops along the airport highway (see Figure 8).

This is confirmed when we look at the level of innovation and differentiation in homogeneous tourism places (HOTP's) that are dominated by differentiated and strongly differentiated jewellers, being fully dependent on foreign tourists.

\section{Level of Differentiation of Shops Selling Clothing, Shoes and Bags and Types of Tourism Places}

Just as jewellers, shops selling clothing, shoes, and bags are hardly active to follow strategies of differentiation. Only 5 of the 50 shops are differentiated and strongly differentiated (table 5). There is a fairly strong relation between level of differentiation of those shops and types of tourism places, as shown in results of the chi-square analysis in Table 6 (chi-square: 21.073 significant at 0.012). The results of the correspondence analysis (Figure 9) show a strong association between standardized clothing, shoes, and bags shops and mixed places with weak tourism functions. These results are, to a large extent, explained by the fact that most of the shops ( 40 of a total of 50) are concentrated in mixed places with weak tourism functions (Table 6), $25 \%$ of which are standardized and $70 \%$ slightly differentiated (Table 6). All this is in line with our findings on hotels and jewellery shops. The low level of differentiation of shops selling clothing, shoes, and bags shops is, at first look, related with the dominance of local customers in the mixed places with weak tourism functions.
Level of differentiation/ Tourism

Areas

MPSTF'S

HOTP'S

HDTP

MPWTF'S

Total

$\begin{array}{lllllll}\mathbf{0} & \mathbf{1} & \mathbf{2} & \mathbf{3} & \text { Total } & \begin{array}{l}\text { Chi } \\ \text { square }\end{array} & \text { p-value } \\ 1(100 \%) & 0(0 \%) & 0(0 \%) & 0(0 \%) & 1(100 \%) & 0.012 & 21.073 \\ 1(33 \%) & 2(67 \%) & 0(0 \%) & 0(0 \%) & 3(100 \%) & & \\ 0(0 \%) & 3(50 \%) & 1(17 \%) & 2(33 \%) & 6(100 \%) & & \\ 10(25 \%) & 28(70 \%) & 2(5 \%) & 0(0 \%) & 40(100 \%) & & \\ 12(24 \%) & 33(66 \%) & 3(6 \%) & 2(4 \%) & 50(100 \%) & & \end{array}$


Figure 9. Relation between level of differentiation of shops selling clothing, shoes and bags and different types of tourism places

Rows: 0: standardized shops, 1: slightly differentiated shops, 2: differentiated shops, 3: strongly differentiated shops. Columns: HOTP's: homogeneous tourism places, HDTP: historical diversified tourism place, MTPSF's: mixed places with strong tourism functions, MPWTF's: mixed places with weak tourism functions.
Figure 10. An example of shops in a bazaarlike building in a homogeneous tourism place

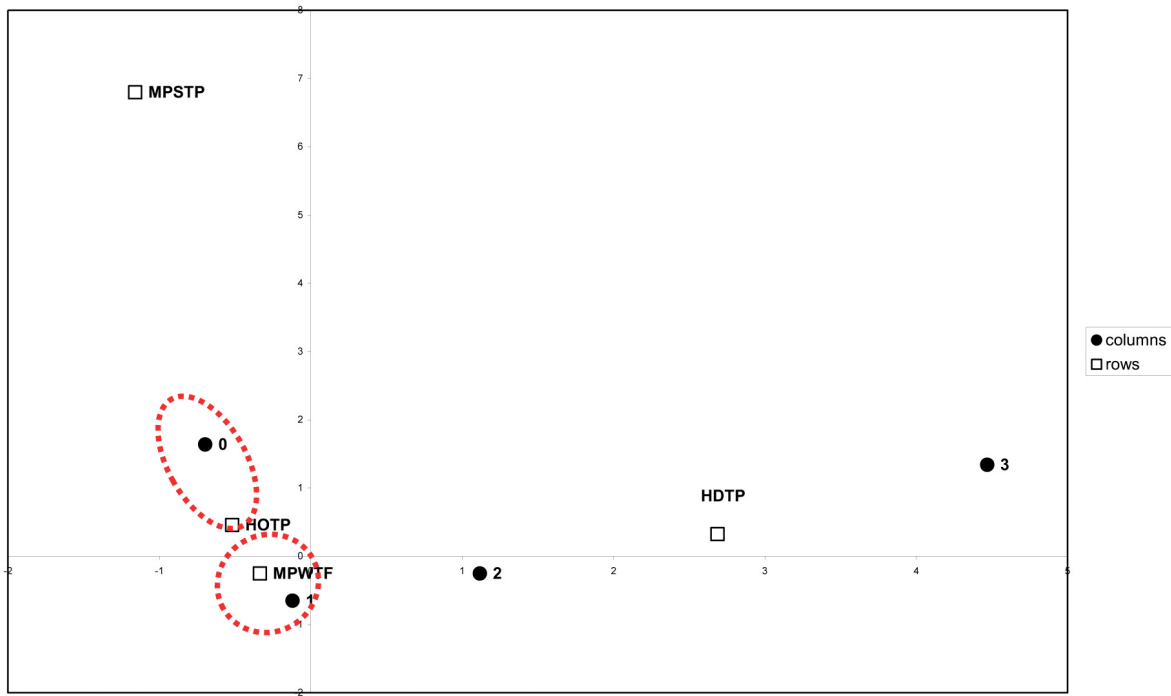

However, shops selling clothing, shoes and bags in homogeneous tourism places also are fairly standardized. While $33 \%$ of these firms in those places are standardized, the remaining $67 \%$ of them are only slightly differentiated (Table 6). The results of the correspondence analysis clearly show a strong association between standardized shops and homogeneous tourism places (Figure 9).

The shops selling clothing, shoes, and bags in these places are, just like jewellers, located in special bazaar-like buildings nearby the 5-star hotels to benefit from the market of tourists staying in those hotels (Figure 10). For that reason, all these shops are completely oriented at the market of foreign tourists staying in this zone. They benefit from external economies of scope due to their proximity to the 5-star hotels and external economies of scale because they are all located in the same buildings. The fact that clothingand leather shops in homogeneous tourism places are fairly standardized -they predominantly sell imitation products of big brands-, suggests that foreign tourist are most interested in standardized clothing and leather products.

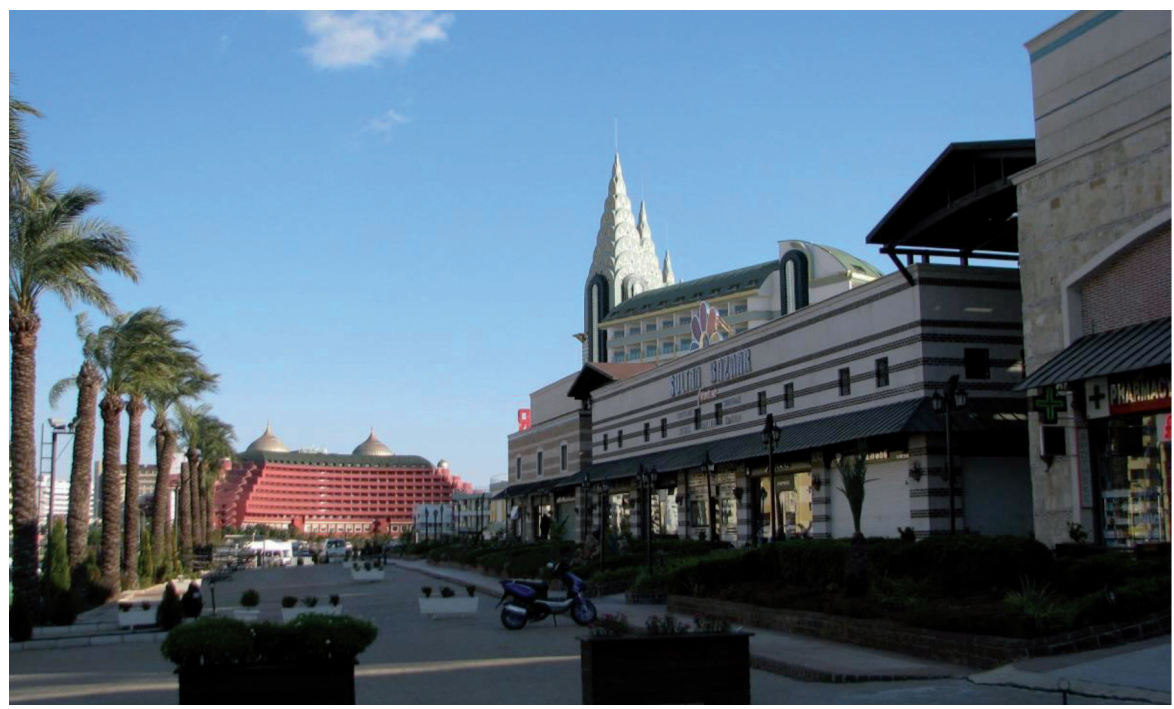


The shops (clothing, shoes, and bags) in the Kaleiçi area, a historically diversified tourism place, are more differentiated than in other tourism places ( $50 \%$ is of them is differentiated and strongly differentiated), as is shown in the correspondence plot (Figure 9). However, no less than $50 \%$ of the shops in this place sell imitation products of big brands.

\section{CONCLUSION}

In this paper we explored the question whether tourism firms in Antalya, a sun-sea-sand mass-tourism city, follow a more active strategy of differentiation in some tourism places within the city than in others. The first assumption we started this research with is that the growth of a sun-sea-sand mass-tourism city is accompanied with a growth of both standardized and differentiated tourism firms, which is supported by other literature on Antalya (Terhorst and Erkuş-Öztürk, 2015; Erkuş-Öztürk and Terhorst, 2016) as well as on other sun-sea-sand mass-tourism places (Torres, 2002). The second assumption we started with is that geography matters in the processes of standardization and differentiation. Some tourism places in the city form a better environment for tourism-firm differentiation than others. By this we do not mean that tourism firms, like all firms, only adapt to their place-specific environment because they are actively involved in the process of place making through their strategic decisions of differentiation.

The empirical results of our research show that, in general, differentiated tourism firms are more found in specific tourism places than in others but, as expected, there are differences between the four researched sectors: hotels, restaurants, jewellers, and shops selling clothing, shoes, and bags.

As hypothesized, hotels in homogeneous tourism places, state-planned tourism zones in the periphery of the city, very actively follow strategies of differentiation. This is explained by the fact that those places are dominated by big (they benefit from internal economies of scale), mainly 5-star hotels, that generally are more innovative than small lower-quality hotels. In addition, these hotels have to diversify their supply of services (and simultaneously benefit from internal economies of scope) because they cannot benefit from external economies of scope. This conclusion is counterintuitive because tourism zones stand for tour-operator dominated all-inclusive mass-tourism. It confirms the idea that mass tourism is less standardized than one is, at first thought, inclined to believe. Hotels in mixed tourism places with weak tourism functions (Antalya's city centre), by contrast, are most standardized, which is in accordance with our third hypothesis. These areas, not very attractive to foreign tourists, are more visited by Turkish tourist than by foreigners as well as by lower- and lower-middle class locals.

In accordance with our second hypothesis, innovative restaurants are predominantly found in Kaleiçi port area, a historically diversified tourism place with a lot of monumental Ottoman buildings, a variegated mix of restaurants and shops visited by well-to-do locals and foreign tourists. This place comes close to Jane Jacob's mixed urban neighbourhoods and is the antipode of a standardized mass-tourism place. This area is visited by "adventurous tourists" (tourists who do not stay in the all -inclusive hotels in the tourism zone) and well-to-do locals, which stimulates restaurants to be innovative here. Due to this mix of visitors their demand is steadily growing (without a strong fall in the off-season) and the quality uncertainty 
of restaurateurs to introduce innovations is reduced. Restaurants in the mixed places with weak tourism functions, by contrast, are most standardized, just as the hotels in these places. It seems that standardized hotels and restaurants benefit from each other in these places (external economies of scope).

The most differentiated jewellers are found in homogeneous tourism places, such as in large shops along the highway to the airport that are predominantly visited by foreign tourists. The craft production of jewels is based on a very long tradition in Turkey and it seems that foreign tourists are very much interested in buying these Turkish-made, "authentic" products, even when they are sold in modernist big buildings along the airport highway. The most standardized jewellers, on the other hand, are located mainly in the mixed places with weak tourism functions, just as standardized hotels and restaurants.

The clothing, shoes, and bags shops generally are not very active to distinguish themselves from others. Most of them sell imitations of brands at relatively low prices. These standardized shops are strongly concentrated in the mixed areas with weak tourism functions and in the shopping malls in the Kundu tourism enclave. The few innovative shops in our sample are located in Kaleiçi port area, the historical diversified tourism place.

The first major conclusion of this empirical research is that tourism firms in all four sectors in mixed places with weak tourism functions are standardized. The types of visitors (more lower- and lower-middle class locals than foreign tourists) and standardized (tourism) firms seem to form a coherent whole. The second major conclusion is that hotels and jewellers in homogeneous tourism places are very innovative. Thus homogeneous mass-tourism places do not only benefit from economies of scale but also from internal as well as external economies of scope. The third major conclusion is that Kaleiçi port area, a historically diversified tourism places, also shows some (weak) coherence in terms of types of visitors and differentiation of restaurants and some shops.

From this research we can also draw two theoretical conclusions. First, a number of tourism researchers have shown that localization and urbanization economies play an important role in the innovativeness of tourism firms (Hall and Williams, 2008, 142-170; Novelli et al. 2006; ErkuşÓztürk, 2016). But their analyses of the role of localization and urbanization economies relate to supply side of firms and are made on a much broader spatial scale than we did in this paper. As argued before, at the subregional scale localization and urbanization economies at the supply side generally are much less important than at the demand side (except in Antalya's tourism zones in which hotels benefit from internal economies of scale and scope at the supply side). Our empirical analysis points to the important role of particularly urbanization economies at the demand side in explaining intra-regional differences in firm differentiation.

Secondly, and not surprisingly from a theoretical point of view, there is only one type of tourism place in Antalya (mixed places with weak tourism functions) that forms a coherent whole in terms of types of visitors and types of (tourism) firms. As argued in the theoretical section of this paper, we do not underscore a structuralist conception of place (see Massey, 2005, 36-42) in which all elements that make up a place form a coherent whole. Tourism places, like all places, are dynamic, not static, as a result of 
which their possible coherence is continually undermined, and, as argued before, (tourism) entrepreneurs in (tourism) places make their strategic decisions without taking into consideration the strategic decisions of other entrepreneurs in the same place, which prevents a place to become fully coherent.

\section{BIBLIOGRAPHY}

BATHELT, H., MALMBERG, A., MASKELL, P. (2004) Clusters and Knowledge: Local Buzz, Global Pipelines and the Process of Knowledge Creation, Progress in Human Geography, (28) 31-56.

BEYHAN, B. (2006) The Role of Labor Mobility in the Cognitive Architecture of an Industrial Cluster: The Case of Siteler in Ankara, Unpublished PhD Thesis, Department of City And Regional Planning, Middle East Technical University, Ankara.

DE PROPRIS, L., LAZZERETTI, L. (2007) The Birmingham Jewellery Quarter: A Marshallian Industrial District, European Planning Studies, 15(10) 1295-325.

ERKUŞ ÖZTÜRK, H. (2009) The Role of Cluster Types and Firm Size in Designing the Level of Network Relations: The Experience from Antalya Tourism Region, Tourism Management, 30(4) 589-97.

ERKUŞ ÖZTÜRK, H. (2016) Diversification of Hotels in a Single-Asset City: Evidence from Antalya. In M. Kozak (Ed), Tourism and Hospitality Management, Emerald Publishing, Bingley, 173-185.

ERKUŞ ÖZTÜRK, H., TERHORST, P. (2015) Economic Diversification of a Single-Asset Tourism City: Evidence from Antalya. Current Issues in Tourism. doi:10.1080/13683500.2015.1091806. (article in press).

ERKUŞ ÖZTÜRK, H., TERHORST, P. (2016) Innovative Restaurants in a Mass-Tourism City: Evidence from Antalya, Tourism Management (54) 477-89.

EWEN, J. M. (2007) Micro-clusters and Networks: the Growth of Tourism, Elsevier; Amsterdam.

FRENKEN, K., BOSCHMA, R. (2007) A Theoretical Framework for Evolutionary Economic Geography: Industrial Dynamics and Urban Growth as a Branching Process, Journal of Economic Geography, 7(5) 635-49.

HALL, C.M., WILLIAMS, A.M. (2008) Tourism and Innovation, Routledge; London.

HIERNAUX NICOLAS, D. (2003) Mexico: Tensions in the Fordist Model of Tourism Development, Cities and visitors. Regulating people, markets, and city space, eds. L.M Hoffman, S.S Fainstein, D.R. Judd. Blackwell, Oxford; 187-99.

HIRSCHMAN, A. O. (1970) Exit, Voice and Loyalty: Responses to Decline in Firms, Organizations, and States. Harvard University Press, Cambridge, MA.

IOANNIDES, D. DEBBAGE, K.G. (1998) Neo-Fordism and Flexible Specialization in the Travel Industry, Dissecting the Polyglot, The Economic Geography of the Tourist Industry. A Supply-Side Analysis, eds. D. Ioannides, K.G. Debbage, Routledge, London, 99-122. 
JACOBS, J. (1961) The Death and Life of Great American Cities. Vintage Books, New York.

JACOBS, J. (1969) The Economy of Cities. Penguin Books, Hammondsworth.

JESSOP, B. (2009) Avoiding Traps, Rescaling States, Governing Europe, Leviathan Undone? Towards a Political Economy of Scale, eds. R. Keil, R. Mahon UBC press, Vancouver; 87-104.

KEMENY, T. H., STORPER, M. (2015) Is Specialization Good for Regional Economic Development? Regional Studies, 49(6), 1003-18.

MALMBERG, A., MASKELL, P. (2002) The Elusive Concept of Localization Economies: Towards a Knowledge-Based Theory of Spatial Clustering, Environment and Planning A, (34) 429-49.

MASSEY, D. (2005) For Space, Sage, London.

MINISTRY OF CULTURE AND TOURISM (2011) Tourism Statistics, Department of the Province of Antalya.

MULLINS, P. (1991) Tourism Urbanization. International Journal of Urban and Regional Research, 15 (3) 326-42.

NOVELLI, M. SCHMITZ, B., SPENCER, T. (2006) Networks, Clusters and Innovation in Tourism: A UK Experience. Tourism Management, 27(6) 1141-52.

OTTENBACHER, M., HARRINGTON, R. (2007) The Innovation Process Of Michelin-Starred Chefs, International Journal of Contemporary Hospitality Management, 19(6), 444-60.

PARR, J.B. (2002) Missing Elements in the Analysis of Agglomeration Economies, International Regional Science Review, 25 (2), 151-68.

PORTER, M.E. (1990) The Competitive Advantage of Nations. Free Press, New York.

RAO, H., MONIN, P., DURAND, R. (2003) Institutional Change in Toque Ville: Nouvelle Cuisine as an Identity Movement in French Gastronomy, American Journal of Sociology, 108(4), 795-843.

SAXENIAN, A. (2006) The New Argonauts. Regional Advantage in a Global Economy. Harvard University Press, Cambridge, MA.

SAYER, A. (2000) Realism and Social Science. Sage, London.

SCHMOOKLER, J. (1966) Invention and Economic Growth. Harvard University Press, Cambridge, M.A.

SCHUMPETER, J.A. (1934) The Theory of Economic Development. An Inquiry into Profits, Capital, Credit, Interest, and the Business Cycle, Harvard University Press, Cambridge, MA.

SINGH, S. (2007) Is There Such A Thing As 'Mass Tourism'?, Tourism Recreation Research, 32 (1) 107-11.

SLEUTJES, B., SCHUTJENS, V. (2013) Anchoring of Firms in the Neighborhood: Does Local Social and Physical Order Affect Local Firms' Investment Strategies?, European Planning Studies, 21 (8) 125675.

SVEJENOVA, S., MAZZA, C., PLANELLOS, M. (2007) Cooking Up Change in Haute Cuisine: Ferran Adrià as an Institutional Entrepreneur, Journal of Organizational Behavior, 28(5) 539-61. 
TELLER, C.H., SCHNEDLITZ, P. (2012) Drivers of Agglomeration Effects in Retailing: The Shopping Mall Tenant's Perspective, Journal of Marketing Management, 28 (9-10) 1043-61.

TERHORST, P., ERKUŞ ÖZTÜRK, H. (2015) Urban Tourism and Spatial Segmentation in the Field of Restaurants: The Case of Amsterdam, International Journal of Culture, Tourism, and Hospitality Research, 9(2) 85-102

TORRES, R. (2020) Cancun's Tourism Development from a Fordist Spectrum of Analysis, Tourist Studies, 2 (1), 87-116.

VAINIKKA, V. (2013) Rethinking Mass Tourism, Tourist Studies, 13(3) 268-86.

Alınd1: 31.05.2016; Son Metin: 01.02.2017 Anahtar Sözcükler: Firma farklılaşması; mekan (yer) farklılaşması; innovasyon; yenileme; turizm kenti; Antalya.

\section{DENIZ-KUM-GÜNEŞ TURİZM KENTİ ANTALYA'DA TURİZM FİRMA VE MEKAN(YER) FARKLILAŞMASI}

Bu çalışma farklı turizm alanlarında yer alan turizm firmalarının daha aktif bir farklılaşma ve innovasyon stratejisi izleyip izlemediklerini ortaya çıkarmayı amaçlamaktadır. Bu kapsamda, çalışma, deniz-kum-güneş turizmi kenti Antalya'daki (Türkiye) yerleşik turizm firmalarının (oteller, restoranlar, kuyumcu ve perakende ticaret firmalarının) farklılaşma ve innovasyon stratejileri ile turizm alan farklılaşması arasındaki ilişkiyi konu edinmektedir. Çalışma önceki çalışmalardan ilk olarak; firma ve turizm mekanı farklılaşması ilişkisini bir turizm mekanı üzerinden incelemesiyle, ikinci olarak da; firma odaklı görüşmelerden elde edilen verilerin ampirik olarak kantitatif yöntemler ile analiz edilmesiyle (ki-kare ve çoklu uyum analizi) farklılaşmaktadır. Bazı türde turizm firmalarının farklı turizm alanlarında daha farklılaşmış ve innovatif bir strateji izlerken, aynı türde turizm firmalarının diğer turizm alanlarında daha standartlaşmış bir strateji izlediği hipotezi test edilmeye çalışılmıştır. Bulgular ilk olarak bütün turizm firma türlerinin düşük turizm fonksiyonu içeren karma alanlarda herhangi bir farklılaşma ve innovasyon stratejisi geliştirmediğini göstermiştir. İkinci olarak anklav turizm alanlarında yer alan otellerin daha innovatif bir farklılaşma stratejisi izlediğini göstermiştir. Son olarak ise, innovasyon düzeyinde farklılaşmış restoran, kuyumcu ve perakende ticaret firmalarının tarihsel olarak çeşitlenmiş turizm alanları ve turizm fonksiyonlarının güçlü olduğu alanlarda anlamlı bir ilişkisi olduğu ortaya çıkmıştır.

\section{TOURISM-FIRM DIFFERENTIATION AND PLACE DIFFERENTIATION IN THE SUN-SEA-SAND TOURISM CITY OF ANTALYA}

This study aims to explore whether tourism firms follow a more active strategy of differentiation in some tourism places than in others. In this context, this study is about the relation between differentiation (innovation and renovation) strategies of incumbent tourism firms (hotels, restaurants, jewellers, and clothing-, shoes-, and bags shops strongly oriented at the tourism market) and tourism-place differentiation in the sun-seasand mass-tourism city of Antalya (Turkey). It differs from previous 
researches: 1) by bringing a tourism dimension to firm differentiation, and tourism place differentiation, and 2) by employing a quantitative method of analysis (correspondence and chi-square) based on a firm-level survey (hotels, restaurants, jewellery- and retail-trade companies). It is hypothesized that (1) hotels in tourism enclaves follow, paradoxically, more actively strategies of differentiation than in other tourism places, (2) mixed places with a variety of tourism and non-tourism firms and a mix of local inhabitants/visitors (historical diversified tourism places and mixed places with strong tourism functions) are the most favourable environment for tourism firms that follow strategies of differentiation, and (3) that tourism firms which realize less or no innovations and/or renovations are predominantly found in mixed places with weak tourism functions predominantly visited by lower and lower-middle class locals. It is found firstly that hotels in tourism enclaves follow more actively strategies of differentiation. Secondly, restaurants, jewellers, and retail-trade shops that actively followed a strategy of differentiation are most likely located in a historical diversified tourism place, and mixed places with strong tourism functions. Thirdly, all tourism firms in mixed places with weak tourism functions mainly visited by lower and lower-middle class locals follow less strategies of innovation and/or renovation than in other tourism places.

HİLAL ERKUŞ ÖZTÜRK; B.CP, M.Sc., PhD.

Received her bachelor's degree in city and regional planning from Dokuz Eylül University. Graduated from the integrated Masters and PhD. Program of the City and Regional Planning Department of the Middle East Technical University in 2008. Her major research interests include urban and regional planning and development, (political) economic geography, tourism geography. herkus@akdeniz.edu.tr, hilalerkus@yahoo.com

PIETER TERHORST; M.Sc., PhD.

Received his M.Sc. from the University of Amsterdam, Department of Human Geography in 1980. Earned his PhD. in human geography from the Department of Geography, Spatial Planning and International Development Studies of the same university in 1997. His major interests are (political) economic geography and urban planning.p.j.f.terhorst@uva.nl 